\title{
EXCITING TIMES AHEAD FOR THE INDIAN PHARMA INDUSTRY
}

Dear Reader,

Coinciding with the $60^{\text {th }}$ Anniversary of IDMA, a true and vibrant transition phase is commencing for your association, its publications and allied activities. Dr. Viranchi Shah, the young and energetic Hon. President from "Vibrant Gujarat" is taking over the reigns of IDMA, with an equally young team of Executive committee members. We are confident that IDMA's flag will fly

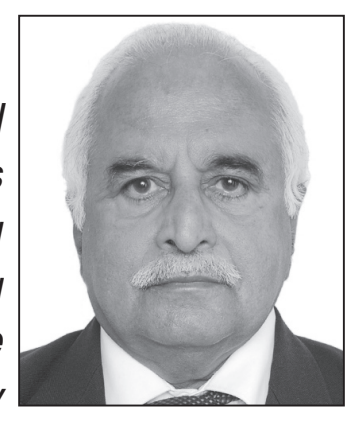
high globally, all the more, in the coming years. It is time that the young (and the long-experienced ones too) get ready for the new integrated and synergised challenges of the 2020's and 2030's to keep pace with the clarion call for intense pharma research and innovation to keep pace with the west and the rest.

As referred in earlier editorials, with the Indian pharma industry entering the proverbial 25-year circle of new IP/Patent law regime (1995 to 2000+), it is time for IDMA and the Indian Pharma Industry to review and revamp its innovative research and patenting strategies. Let us admit and appreciate that the Indian Pharma Industry has come a long way and has established its rightful place in the global arena of generic pharma. Let us replicate this in the field of innovation and IPR protection too. Let us hope and take note that the recent meetings of IDMA under the emerging leadership of Dr. Viranchi Shah, both with USFDA-Country Director Dr. Sarah McMullen and the few representatives of US Pharma Industry, both at Ahmedabad, are only the beginning of a long standing, durable and mutually beneficial relationship with the US and Indian Pharma Industries and more importantly with the regulatory authority, USFDA.

The days of the Indian Pharma Industry pleading for waivers and exemptions must be left behind. Let India and South Africa seek waiver of patent rights in context of the larger public interest. IDMA and the Indian Pharma Industry has always worked for the best interests of the patients and the community at large, not only in India but across the world. This will continue with invigorated vision and mission under the new IDMA leadership. Requests for abolition of patent rights on Human Rights considerations and as a fundamental right of freedom to operate under the Constitution of India are passé. We have left behind such thoughts of the eighties and nineties and have marched forward with strong self-belief, self-respect and vigorous will and pursuit to achieve a global leadership position not only in the 
pharma bio-vaccine industry, but also in pharmaceutical innovation and building an outlicencing oriented patent portfolio along with high regulatory standards of new innovative molecules and dosage forms to meet the increasing expectations and needs of the Indian and third world country communities.

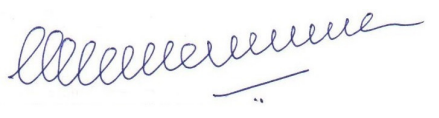

Dr. Gopakumar G. Nair

Editor Indian Drugs

https://doi.org/10.53879/id.58.11.p0005

About the Editor
Dr. Gopakumar G. Nair is a Ph.D in Organic Chemistry (1966) from National Chemical Laboratory,
Pune (Pune University). He was a Post-Doctoral fellow at IIT Bombay, Powai (1967) before joining the
Pharma Industry. He was Director of Bombay Drug House P. Ltd., later Chairman of BDH Industries
Ltd. as well as CMD of Bombay Drugs \& Pharma Ltd., which was merged with Strides Arcolab Ltd. in
2001. Dr. Nair served IDMA as office bearer for many years from 1972 onwards and was Chairman
of various Committees for nearly 4 decades. He was the President of IDMA in 1999/2000. Currently,
Dr. Nair is the Chairman of the IPR Committee in IDMA.
Having moved into the Intellectual Property field, he was the Dean of IIPS (Institute of Intellectual
Property Studies) at Hyderabad in 2001/2002. Later, he set up his own boutique IP firm, Gopakumar
Nair Associates, as well as Gnanlex Hermeneutics Pvt. Ltd., having done his L. L. B. from Mumbai
University. He is also CEO of Patent Gurukul and President of Bharat Education Society, Kurla,
Mumbai, managing many educational institutions in and around Mumbai.
D

If you would like to comment on the editorial please write to us at publications@idmaindia.com 